\title{
Research Communication \\ Circulating sCD138 and Some Angiogenesis-Involved Cytokines Help to Anticipate the Disease Progression of Early-Stage $B$-Cell Chronic Lymphocytic Leukemia
}

\author{
Dariusz Wołowiec, Jarosław Dybko, Tomasz Wróbel, Donata Urbaniak-Kujda, Bożena Jaźwiec, \\ Beata Tomaszewska-Toporska, Katarzyna Kapelko-Słowik, Stanisław Potoczek, and \\ Kazimierz Kuliczkowski
}

Department of Hematology, Wrocław Medical University, Pasteura 4, 50-367 Wrockaw, Poland

Received 4 December 2005; Revised 12 March 2006; Accepted 13 March 2006

Syndecan-1 (CD138) is a transmembrane heparin sulfate proteoglycan expressed on distinct stages of differentiation of $B$ lymphoid cells. Its prognostic value in $B$-cell chronic lymphocytic leukemia ( $B$-CLL) has not been evaluated so far. The serum concentration of sCD138 and some angiogenesis-involved cytokines: vascular endothelial growth factor (VEGF), basis fibroblast growth factor (bFGF), and endostatin were studied in 52 previously untreated patients with $B$-CLL. We found that bFGF and sCD138 levels were significantly higher in B-CLL patients than in controls. In patients with sCD138 level or endostatin level below the median value the lymphocyte count was higher than in patients with serum level of those cytokines above the median value. In patients with progressive disease bFGF level was significantly higher and sCD138 level significantly lower than in patients with stable one. Moreover, high sCD138 level was associated with longer lymphocyte doubling-free survival, and, on the limit of statistical significance, a high endostatin level was associated with shorter progression-free survival. We conclude that serum sCD138 level is increased in early stage B-CLL patients and may have a positive prognostic value as to the dynamics of the disease.

Copyright (C) 2006 Dariusz Wołowiec et al. This is an open access article distributed under the Creative Commons Attribution License, which permits unrestricted use, distribution, and reproduction in any medium, provided the original work is properly cited.

\section{INTRODUCTION}

Clinical picture of the $B$-cell chronic lymphocytic leukemia (B-CLL) depends not only on the biological features of leukemic lymphocytes but also on their environment, in particular on the serum level of different cytokines. Some of them are involved in the cell proliferation, maturation, and survival, some other participate in the regulation of cell adhesion and in the angiogenesis. In particular, tumor progression is profoundly influenced by cell-to-cell or cell-tomatrix interactions mediated by transmembrane proteoglycans. Syndecans are members of a family of cell surface transmembrane heparin sulfate proteoglycans which are involved in the cell adhesion to the extracellular matrix acting as receptor for such matrix elements as collagen, fibronectin, thrombospondin, and tenascin. They are also receptors for heparin-binding growth factors [1-3]. Syndecan1 (sCD138), although expressed mainly by epithelial cells, seems also to play a role in the differentiation and survival of the $B$ lymphocyte lineage cells. In mice it is detectable on pre$B$ cells, lost in mature $B$ cells, and reexpressed on plasma cells
[4]. In patients with multiple myeloma CD138 is expressed on malignant plasma cells both in bone marrow and in peripheral blood and its ectodomain is shed from their surface into culture medium in vitro and into the serum in vivo [5]. In addition to its role in cell-matrix adhesion and cell-cell adhesion between myeloma cells, it has been shown that CD138 influences bone cell differentiation, promotes myeloma cell apoptosis, and exerts an inhibitory effect on their proliferation by downregulating cyclin D1 expression $[6,7]$. Elevated serum sCD138 level is an independent unfavorable prognostic parameter in multiple myeloma [8]. However, up to now much less is known about the expression and clinical role of CD138 in other $B$-lineage-derived malignancies. In the difference to the normal and malignant T cells, or CD5+ lymphocytes other than $B$-CLL lymphocytes, its expression was found in $B$-CLL and lymphoplasmacytoid cells. It was therefore proposed that CD138 expression might be used as a phenotypic marker for this group of $B$-cell malignancies $[9,10]$. Despite this observation which indicates that CD138 may play a role in the pathogeny of $B$-CLL, no studies on the serum level of sCD138 and its possible prognostic value 
in B-CLL patients have been published so far. We evaluated then the serum level of sCD138 in early B-CLL patients in relationship to the disease aggressiveness. In addition, we assessed the serum level of principal cytokines involved in the angiogenesis, such as vascular endothelial growth factor (VEGF), basic fibroblast growth factor (bFGF), and endostatin.

\section{PATIENTS}

Fifty-two previously untreated patients ( 30 men, 22 women), aged from 36 to 83 years (median 67), and 12 healthy agematched volunteers were included to the study. In all patients the diagnosis of $B$-CLL was established according to the $\mathrm{Na}$ tional Cancer Institute- (NCI-)Sponsored Working Group diagnostic criteria for CLL [11]. According to Rai classification, 18 patients were in stage 0 , whereas 26 were in stage I, and remaining 8 were in stage II. An assessment of history and a physical examination was performed as initial diagnostic procedure. Each patient was described by following diagnostic tests: complete blood count, liver and renal function tests, immunoglobulins, LDH, $\beta 2$-microglobulin level, bone marrow aspiration, immunophenotyping of peripheral blood lymphocytes (PBLs) including CD38 positivity, chest $\mathrm{X}$-ray, and abdominal ultrasound. In 19 patients bone marrow trephine biopsy was evaluable for the assessment of bone marrow infiltration pattern.

Follow-up period ranged from 12 to 37 months (median 31). During this period the cytostatic treatment was started in 23 patients because of the disease progression according to the recommendations of the NCI-Sponsored Working Group diagnostic criteria for CLL [11]. In 16 patients the indication was the rapid increase of PBL, that is, lymphocytosis doubling time (LDT) shorter than 1 year. In the remaining 7 the treatment was administered because of the appearance of other signs of progressive disease: thrombocytopenia or the rapid increase of spleen or lymph nodes. During the treatment-free period the appearance of higher stage according to Rai classification was stated in 5 patients. The remaining 29 patients did not need treatment during the whole follow-up period. The mean follow-up period was similar for patients who received cytostatic treatment and for those who did not require therapy (29.2 and 29.6 months, resp).

In 44 patients PBL did not double within one year following the enrolment to the study. In 8 remaining patients LDT was no longer than 12 months, and those patients started to be treated for this reason. Two other patients had to undergo the cytostatic treatment within 12 months after the enrolment to the study for other indications than the rapid increase of PBL.

Prognostic values of the initial cytokine concentrations were assessed for patients with LDT no longer than 12 months versus those in whom the PBL doubling took more than one year, and for patients with disease progression (ie, patients who needed cytostatic treatment in any moment) (23 patients) versus those with stable disease during the whole follow-up period.

\section{METHODS}

\section{Serum sampling and cytokine determination}

The serum was obtained from each patient and stored at $-80^{\circ} \mathrm{C}$ until measurements. All specimens were collected with the consent of the donor. The cytokine serum concentrations were assayed by following specific enzyme-linked immunoassay kits: VEGF, bFGF (R \& D Systems Inc, Minneapolis, USA), sCD138 (Diaclone, Besanon, France), and endostatin (Chemicon, UK). Standards and samples were assayed as duplicates, and interassay variations were within the range given by manufacturer. The project was performed in accordance with the Helsinki Declaration with the approval of the Local Ethics Committee.

\section{Apoptosis assessment}

Cells were obtained from 25 patients included to the study at the same time as their sera. Mononuclear cells were isolated from peripheral blood by standard centrifugation over $1.077 \mathrm{~g} / \mathrm{mL}$ gradient (Gradisol L, Aqua Medica, Poland). They were incubated over 24 hours in RPMI1640 medium supplemented with $10 \%$ heath-inactivated fetal calf serum (Invitrogen, UK) and antibiotics at $37^{\circ} \mathrm{C}$ and in $5 \% \mathrm{CO}_{2}$ humidified atmosphere. Spontaneous apoptosis of PBL was then cytofluorometrically assessed after annexin V/propidium iodide staining (Becton Dickinson PharMingen, USA). Cells positively stained with annexin V only and both with annexin $\mathrm{V}$ and propidium iodide were considered as apoptotic.

\section{Statistical analysis}

Comparisons of values were performed with Mann-Whitney test. Relationship between continuous variables was established with Pearson's correlation coefficient. A cumulative probability of survival without lymphocyte doubling (lymphocyte doubling-free survival, LDFS) and of survival without progression, that is, before the appearance of an event which justified the cytostatic treatment (progression-free survival, PFS), was calculated according to Kaplan-Meyer method. We used as the endpoints the doubling of PBL count and the beginning of the treatment, respectively. KaplanMeyer curves were compared with the F-Cox test. A $P<.05$ was considered as the level of statistical significance.

\section{RESULTS}

The serum levels of VEGF, sCD138, and endostatin were measurable in all healthy individuals and $B$-CLL patients. We detected bFGF in sera of all B-CLL patients and in two healthy subjects. Both bFGF and sCD138 levels were significantly higher in B-CLL patients than in healthy controls (median value $18.4 \mathrm{pg} / \mathrm{mL}$ and $0.2 \mathrm{pg} / \mathrm{mL}$ for bFGF; $149.0 \mathrm{ng} / \mathrm{mL}$ and $36.7 \mathrm{ng} / \mathrm{mL}$ for sCD138, resp, for B-CLL patients and for control group) (Table 1). The serum levels of two other cytokines were not significantly different between patients and controls. 
TABLE 1: Comparison of serum levels (median, minimal, and maximal values) of VEGF, bFGF, syndecan 1 , and endostatin in the healthy control group and in 52 untreated $B$-CLL patients.

\begin{tabular}{|c|c|c|c|c|c|c|c|c|c|}
\hline \multirow{3}{*}{ Cytokine } & \multirow[b]{2}{*}{$\begin{array}{l}\text { Controls } \\
N=12\end{array}$} & \multicolumn{5}{|c|}{$B$-CLL patients } & \multirow{2}{*}{\multicolumn{3}{|c|}{$P$}} \\
\hline & & $\begin{array}{c}\text { All } \\
\text { patients } \\
N=52\end{array}$ & $\begin{array}{c}\text { LDT }<12 \\
\text { months } \\
N=10\end{array}$ & $\begin{array}{c}\mathrm{LDT} \geq 12 \\
\text { months } \\
N=42\end{array}$ & $\begin{array}{c}\text { Stable } \\
\text { Disease } \\
N=30\end{array}$ & $\begin{array}{c}\text { Progressive } \\
\text { Disease } \\
N=22\end{array}$ & & & \\
\hline & 1 & 2 & 3 & 4 & 5 & 6 & $\begin{array}{c}1 \\
\text { versus } \\
2\end{array}$ & $\begin{array}{c}3 \\
\text { versus } \\
4\end{array}$ & $\begin{array}{c}5 \\
\text { versus } \\
6\end{array}$ \\
\hline $\begin{array}{l}\text { VEGF } \\
\mathrm{pg} / \mathrm{mL}\end{array}$ & $\begin{array}{c}456.2 \\
(122.4-1029.6)\end{array}$ & $\begin{array}{c}326.5 \\
(84.5-1547.8)\end{array}$ & $\begin{array}{c}247.43 \\
(89.2-762.9)\end{array}$ & $\begin{array}{c}351.9 \\
(84.5-1547.8)\end{array}$ & $\begin{array}{c}326.5 \\
(84.5-833.4)\end{array}$ & $\begin{array}{c}322.3 \\
(89.2-1547.8)\end{array}$ & NS & NS & NS \\
\hline $\begin{array}{l}\mathrm{bFGF} \\
\mathrm{pg} / \mathrm{mL}\end{array}$ & $\begin{array}{c}0.2 \\
(0.0-2.4)\end{array}$ & $\begin{array}{c}18.4 \\
(0.0-529.5)\end{array}$ & $\begin{array}{c}11.64 \\
(0.0-153.2)\end{array}$ & $\begin{array}{c}20.9 \\
(0.0-529.5)\end{array}$ & $\begin{array}{c}16.4 \\
(3.3-120.7)\end{array}$ & $\begin{array}{c}20.9 \\
(0.0-529.5)\end{array}$ & .00001 & NS & .03 \\
\hline $\begin{array}{l}\text { sCD138 } \\
\mathrm{ng} / \mathrm{mL}\end{array}$ & $\begin{array}{c}36.7 \\
(17.4-135.8)\end{array}$ & $\begin{array}{c}149.0 \\
(13.2-257.1)\end{array}$ & $\begin{array}{c}54.2 \\
(13.2-201.2)\end{array}$ & $\begin{array}{c}178.8 \\
(18.4-257.1)\end{array}$ & $\begin{array}{c}187.9 \\
(27.3-257.1)\end{array}$ & $\begin{array}{c}65.1 \\
(13.2-257.1)\end{array}$ & .0002 & .03 & .03 \\
\hline $\begin{array}{l}\text { Endostatin } \\
\mathrm{pg} / \mathrm{mL}\end{array}$ & $\begin{array}{c}5.9 \\
(2.1-12.0)\end{array}$ & $\begin{array}{c}8.12 \\
(2.3-20.6)\end{array}$ & $\begin{array}{c}8.38 \\
(3.8-9.9)\end{array}$ & $\begin{array}{c}8.12 \\
(2.3-20.6)\end{array}$ & $\begin{array}{c}7.56 \\
(2.3-18.5)\end{array}$ & $\begin{array}{c}9.34 \\
(3.8-20.6)\end{array}$ & NS & NS & NS \\
\hline
\end{tabular}

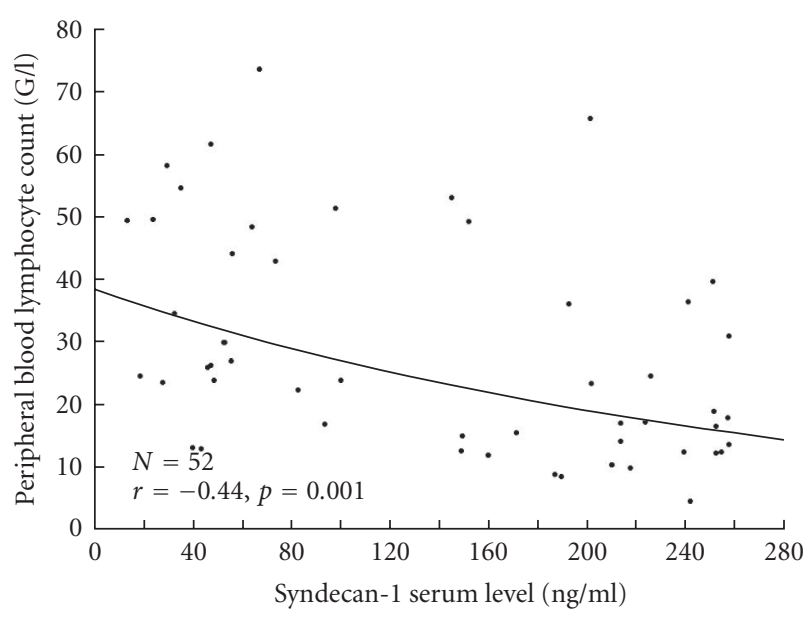

Figure 1: Relationship between Syndecan-1 serum level and peripheral blond lymphocyte count in 52 untreated $B$-CLL patients (the exponential curve is a supportive visualization).

Considering the relationship between cytokine levels and biological variables, a negative correlation between $\mathrm{PBL}$ and sCD138 was found $(r=-0.44, P=.001)$ (Figure 1). According to that, the lymphocyte count was significantly lower in patients with sCD138 level above median value (ie, $149.0 \mathrm{ng} / \mathrm{mL}$ ) than in patients with $\mathrm{sCD} 138$ level below this value $(20.8 \pm 14.3 \mathrm{G} / \mathrm{L}$ versus $35.9 \pm 16.9 \mathrm{G} / \mathrm{L}, P<$ .01). Similarly, the lymphocyte count was significantly lower in patients with endostatin level above median value (ie, $8.1 \mathrm{ng} / \mathrm{mL}$ ) as compared to patients with endostatin level be- low median value $(21.5 \pm 15.9 \mathrm{G} / \mathrm{L}$ versus $29.0+14.1 \mathrm{G} / \mathrm{L}, P$ $.05)$. However, the correlation between these variables was not statistically significant $(r=-0.25, P=.1)$. We found a positive correlation between VEGF level and platelet count $(r=0.45, P=.003)$. We did not state other correlations between cytokines tested and the following parameters: PBL, hemoglobin level, platelet count, 2-microglobulin level, LDH activity, CD38 expression, or bone marrow infiltration pattern.

As shown in Table 1, in patients with progressive disease bFGF level was significantly higher, and sCD138 level was significantly lower as compared with stable disease. sCD138 level was significantly lower in patients who doubled their PBL within one year than in those with slower increase of the lymphocyte number.

The analysis of LDFS and PFS curves after stratifying the patients according to the median values of each cytokine revealed that high $\mathrm{SCD} 138$ level was associated with longer LDFS (Figure 2) and, on the limit of statistical significance, a high endostatin level was associated with shorter PFS (Figure 3). PFS was longer in patients with sCD138 serum concentration above median value, and LDFS was shorter in patients with endostatin concentration above median value but differences between respective curves were not significant ( $P=.14$ for both pairs, not shown). The levels of the other cytokines did not influence LDFS or PFS. For other biological variables, only initial lymphocytosis below the median value was associated with longer PFS.

The spontaneous apoptosis of lymphocytes after 24-hour culture ranged from 3.75 to $42.9 \%$ (median: 12.1 ). There was no correlation between the percentage of apoptotic cells and the serum concentration of sCD138 $(r=-0.17, P=.44)$ or any other biological variables tested. 


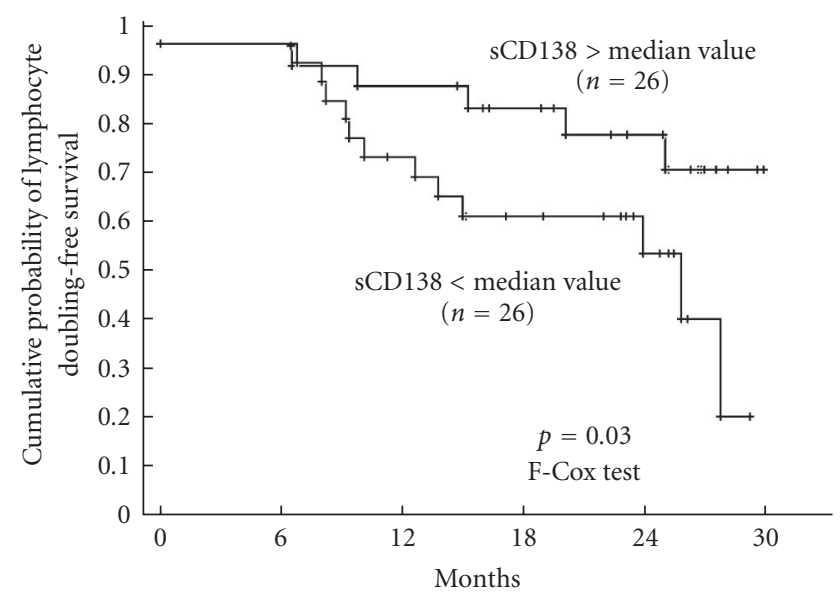

FIGURE 2: Cumulative probability of lymphocyte doubling-free survival in 52 untreated CLL patients stratified on the basis of median value of sCD138 (ie, $149.03 \mathrm{ng} / \mathrm{mL}$ ).

\section{DISCUSSION}

Syndecan-1 is a cytokine supposed to play a role in the differentiation and survival of the $B$ lymphocyte lineage cells. It promotes myeloma cell apoptosis and exerts an inhibitory effect on their proliferation, and the elevated serum level of its soluble form (sCD138) is an independent unfavorable prognostic parameter [5-8]. The observation that CD138 is detectable on B-CLL lymphocytes but not on other CD5positive lymphoma cells [9] raises the possibility that its expression may be related in some way to the pathogeny of this disease. We attempted then to check if sCD138 is also detectable in sera of $B$-CLL patients and if, like in multiple myeloma, its serum level is related to biological features and clinical outcome of this disorder. As the clinical stage is one of the strongest prognostic factors we limited our study to group of low and intermediate risk patients, that is, patients with 0 , I, or II stage according to Rai classification. For prognostic studies we considered two events: doubling of the PBL number and progression of the disease. Because of the small number of patients in whom the progression of Rai stage occurred during the follow-up period, we could not use this event as a criterion of progressive disease. We decided then to consider as "progressive disease" group the cases with necessity of cytostatic treatment. Patients who did not receive any treatment during the whole follow-up were then considered as stable disease group.

We stated that the serum concentration of sCD138 was detectable in all B-CLL patients and was significantly higher than in age-matched healthy controls. An unexpected finding was the negative relationship between its serum level and PBL. Moreover, the sCD138 level was significantly lower in patients with progressive disease when compared to the indolent one, and in patients who doubled their PBL within one year than in those with slower increase of the lymphocyte number.

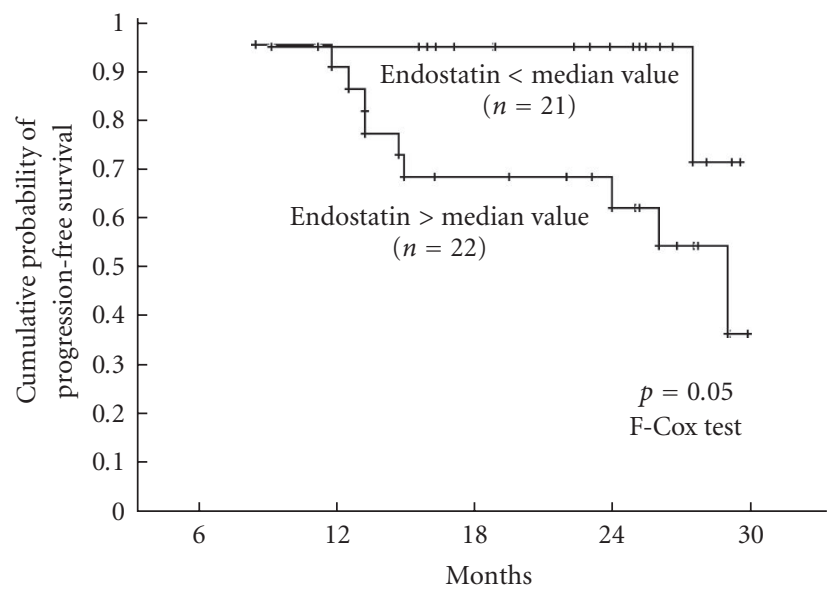

FIGURE 3: Cumulative probability of progression-free survival in 52 untreated CLL patients stratified on the basis of median value of endostatin (ie, $8.12 \mathrm{ng} / \mathrm{mL}$ ).

In line with the latter finding, the cumulative probability of the doubling of PBL was lower in the group with sCD138 level below median value as compared to the patients with higher sCD138 level. This observation is different from what is currently known about the negative prognostic value of sCD138 in multiple myeloma. The relationship demonstrated by us is difficult to explain, but it seems possible that CD138 may promote the apoptosis and hamper the cell cycle progression of B-CLL lymphocytes as it does in plasma cells in in vitro model [6]. We assessed then a relationship between the ability of PBL to undergo spontaneous apoptosis in vitro and serum sCD138 level of patients the lymphocytes were collected from. We did not find a correlation between serum sCD138 level and the percentage of apoptotic lymphocytes after 24-hour culture, but the lack of such correlation in in vitro experimental conditions does not necessarily mean that syndecan-1 does not influence the survival of leukemic lymphocytes in vivo. Firstly, it is well known that the ability of $B$-CLL lymphocytes to undergo spontaneous apoptosis in vitro does not correspond to the inhibition of their apoptosis in vivo. Secondly, a postulated proapoptotic action of syndecan-1 in vivo or in vitro may require cooperation with some other cytokines present in patients serum. The hypothesis that serum sCD138 influences the survival of circulating lymphocytes of CLL patients requires then confirmation by further studies. As other biological variables which we tested were not correlated with the serum level of this cytokine, the relationship with sCD138 level and lymphocytosis seems not to be a "secondary effect" of the influence of this cytokine on some other parameter interrelated with the lymphocyte count.

We also studied the levels of some cytokines known to be involved in the angiogenesis in B-CLL. bFGF is a pleiotropic cytokine which induces angiogenesis and is a ligand for syndecan-1 [12-14]. It upregulates the expression of bcl-2 in B-CLL cell lines resulting in delaying apoptosis [15] what 
may lead in vivo to the enhanced accumulation of long-living $B$-CLL lymphocytes and to the disease progression. Several authors found that serum bFGF level was higher in patients in advanced or progressive $B$-CLL than in patients with $B$ CLL in early Rai stages or stable one [16-18]. In contrast, Molica et al $[19,20]$ analyzed a group of Binet stage A patients and found a correlation of serum bFGF and Rai substages but not with PBL or disease progression. In our study, carried out also on early stage-CLL (Rai 0, I, and II), bFGF was higher in patients in progressive disease than in patients with stable one. Our results seem then to confirm some previously published observations that elevated concentration of this cytokine may herald rapid progression of early B-CLL.

Several studies attempted to establish the importance of serum VEGF, one of the key molecules involved in the angiogenesis, for the clinical behavior of B-CLL. Some authors found a correlation between the serum concentration of VEGF with a number of clinical and biological parameters [21-23] as well as the increased risk of the disease progression in patients with elevated level of this cytokine. In contrast, Molica et al [24], in his first study published on this topics performed on early stage $B$-CLL patients, did not observe a relationship between VEGF level and PBL, bone marrow histology, $\beta 2$-microglobulin, LDH, or interleukin6 level. In our study we observed the previously described positive correlation between serum VEGF and platelet count [16], but not with PBL, hemoglobin level, $\beta 2$-microglobulin level, LDH activity, CD38 expression, or bone marrow infiltration pattern. We also did not find a prognostic value of this cytokine for the disease progression or LDT, which may be due to a relatively short follow-up period (median: 31 months) of our patients' cohort.

Finally we determined the serum level of endostatin, a $C$-terminal fragment of collagen XVIII, an endogenous inhibitor of endothelial proliferation and tumor growth, having a property to inhibit in vivo the angiogenesis and the growth of both primary tumors and metastases [25]. Its serum level was investigated in several solid tumors, and in some of them (clear cell renal carcinoma and soft-tissue sarcoma) it was higher than in healthy controls and associated with increased risk of tumor recurrence [26-28]. Differently from the findings of Góra-Tybor et al [29] performed on patients on both early and advanced stages of $B$-CLL, we did not reveal a difference in the level of his cytokine between patients with stable and progressive disease. However, the cumulative probability of progression-free survival was higher (on the limit of statistical significance) in patients with endostatin level below the median value as compared with the group with lower level of this cytokine. It is difficult to explain why the increased level of this cytokine known as antiproliferative and antiangiogenetic agent might be associated with worse prognosis, but negative prognostic value of high endostatin level for was also found for overall survival in acute myeloid leukemia/myelodysplastic syndrome [30], and for the tumor recurrence of soft-tissue sarcoma [26]. The prognostic value of serum endostatin level in B-CLL needs then further studies on a larger cohort of patients and with longer follow-up period.
In conclusion, serum sCD138 level is higher in early stage $B$-CLL patients than in healthy controls, correlates negatively with peripheral blood lymphocyte count, and is higher in patients with more indolent disease course. Furthermore, bFGF level is higher in patients with progressive disease. The prognostic significance of VEGF for the risk of disease progression requires further studies. Finally, elevated endostatin level, despite its properties as an antiangiogenic and antiproliferative agent as shown on animal models, may have negative prognostic significance as to the probability of disease progression.

\section{REFERENCES}

[1] Ruoslahti E, Yamaguchi Y. Proteoglycans as modular of growth factor activities. Cell. 1991;64:867-869.

[2] Bernfield M, Kokenyesi R, Kato M, et al. Biology of the sydecans: a family of four transmembrane heparan sulphate proteoglycans. Annual Review of Cell Biology. 1993;8:365-393.

[3] Elenius K, Jalkanen M. Function of the syndecans: a family of cell surface proteoglycans. Journal of Cell Science. 1994; 107(11):2975-2982.

[4] Sanderson RD, Lalor P, Bernfield M. B lymphocytes express and lose syndecan at specific stages of differentiation. Cell Regulation. 1989;1(1):27-35.

[5] Dhodapkar MV, Kelly T, Theus A, Athota AB, Barlogie B, Sanderson RD. Elevated levels of shed syndecan-1 correlate with tumour mass and decreased matrix metalloproteinase9 activity in the serum of patients with multiple myeloma. British Journal of Haematology. 1997;99(2):368-371.

[6] Dhodapkar MV, Abe E, Theus A, et al. Syndecan-1 is a multifunctional regulator of myeloma pathobiology: control of tumor cell survival, growth, and bone cell differentiation. Blood. 1998;91(8):2679-2688.

[7] Ridley RC, Xiao H, Hata H, Woodlif J, Epstein J, Sanderson RD. Expression of syndecan regulates human myeloma plasma cell adhesion to type I collagen. Blood. 1993;81(3):767-774.

[8] Seidel C, Sundan A, Hjorth M, et al. Serum syndecan-1: a new independent prognostic marker in multiple myeloma. Blood. 2000;95(2):388-392.

[9] Sebestyen A, Berczi L, Mihalik R, Paku S, Matolcsy A, Kopper L. Syndecan-1 (CD138) expression in human non-Hodgkin lymphomas. British Journal of Haematology. 1999;104(2):412419.

[10] Witzig TE, Kimlinger T, Stenson M, Therneau T. Syndecan1 expression on malignant cells from the blood and marrow of patients with plasma cell proliferative disorders and Bcell chronic lymphocytic leukemia. Leukemia and Lymphoma. 1998;31(1-2):167-175.

[11] Cheson BD, Bennett JM, Grever M, et al. National Cancer Institute-Sponsored Working Group guidelines for chronic lymphocytic leukemia: revised guidelines for diagnosis and treatment. Blood. 1996;87(12):4990-4997.

[12] Bertolini F, Paolucci M, Peccatori F, et al. Angiogenic growth factors and endostatin in non-Hodgkin's lymphoma. British Journal of Haematology. 1999;106(2):504-509.

[13] Basilico C, Moscatelli D. The FGF family of growth factors and oncogenes. Advances in Cancer Research. 1992;59:115-165.

[14] Bikfalvi A, Han ZC. Angiogenic factors are hematopoietic growth factors and vice versa. Leukemia. 1994;8(3):523-529.

[15] Konig A, Menzel T, Lynen S, et al. Basic fibroblast growth factor (bFGF) upregulates the expression of bcl- 2 in B cell chronic 
lymphocytic leukemia cell lines resulting in delaying apoptosis. Leukemia. 1997;11(2):258-265.

[16] Bairey O, Zimara Y, Shaklai M, Rabizadeh E. Bcl-2 expression correlates positively with serum basic fibroblast growth factor (bFGF) and negatively with cellular vascular endothelial growth factor (VEGF) in patients with chronic lymphocytic leukaemia. British Journal of Haematology. 2001;113(2):400406.

[17] Duensing S, Atzpodien J. Increased intracellular and plasma levels of basic fibroblast growth factor in B-cell chronic lymphocytic leukemia. Blood. 1995;85(7):1978-1979.

[18] Christiansen I, Gidlof C, Wallgren A, Simonsson B, Tottermann TH. Serum levels of soluble intercellular adhesion molecule 1 are increased in chronic B-lymphocytic leukemia and correlate with clinical stage and prognostic markers. Blood. 1994;84(9):3010-3016.

[19] Molica S, Vacca A, Ribatti D, et al. Prognostic value of enhanced bone marrow angiogenesis in early B-cell chronic lymphocytic leukemia. Blood. 2002;100(9):3344-3351.

[20] Molica S, Vitelli G, Levato D, Ricciotti A, Digiesi G. Clinicoprognostic implications of increased serum levels of vascular endothelial growth factor and basic fibroblastic growth factor in early B-cell chronic lymphocytic leukaemia. British Journal of Cancer. 2002;86(1):31-35.

[21] Aguayo A, Kantarjian H, Manshouri T, et al. Angiogenesis in acute and chronic leukemias and myelodysplastic syndromes. Blood. 2000;96(6):2240-2245.

[22] Chen H, Treeweeke AT, West DC, et al. In vitro and in vivo production of vascular endothelial growth factor by chronic lymphocytic leukemia cells. Blood. 2000;96(9):3181-3187.

[23] Kini AR, Kay NE, Peterson LC. Increased bone marrow angiogenesis in B cell chronic lymphocytic leukemia. Leukemia. 2000;14(8):1414-1418.

[24] Molica S, Vitelli G, Levato D, Gandolfo GM, Liso V. Increased serum levels of vascular endothelial growth factor predict risk of progression in early B-cell chronic lymphocytic leukaemia. British Journal of Haematology. 1999;107(3):605-610.

[25] O'Reilly M, Boehm T, Shing Y, et al. Endostatin: an endogenous inhibitor of angiogenesis and tumor growth. Cell. 1997;88(2):277-285.

[26] Feldman AL, Pak H, Yang JC, Alexander HR Jr, Libutti SK. Serum endostatin levels are elevated in patients with soft tissue sarcoma. Cancer. 2001;91(8):1525-1529.

[27] Feldman AL, Tamarkin L, Paciotti GF, et al. Serum endostatin levels are elevated and correlate with serum vascular endothelial growth factor levels in patients with stage IV clear cell renal cancer. Clinical Cancer Research. 2000;6(12):4628-4634.

[28] Yamagata M, Shiratori Y, Dan Y, et al. Serum endostatin levels in patients with hepatocellular carcinoma. Annals of Oncology. 2000;11(6):761-762.

[29] Góra-Tybor J, Błoński JZ, Robak T. Circulating proangiogenic cytokines and angiogenesis inhibitor endostatin in untreated patients with chronic lymphocytic leukemia. Mediators of Inflammation. 2003;12(3):167-171.

[30] Lai R, Estey E, Shen Y, et al. Clinical significance of plasma endostatin in acute myeloid leukemia/myelodysplastic syndrome. Cancer. 2002;94(1):14-17. 


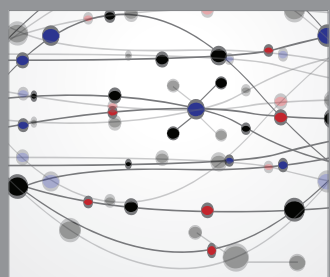

The Scientific World Journal
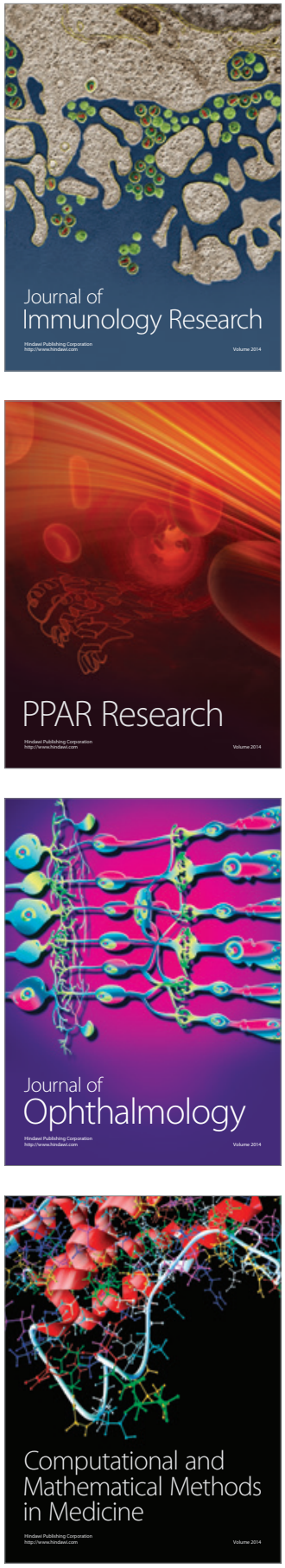

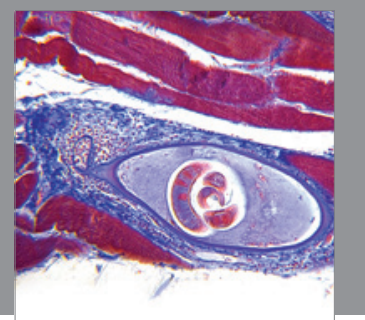

Gastroenterology

Research and Practice
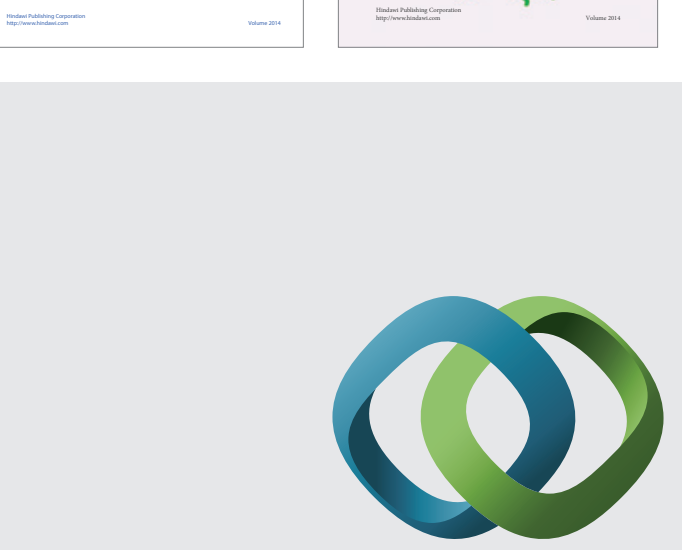

\section{Hindawi}

Submit your manuscripts at

http://www.hindawi.com
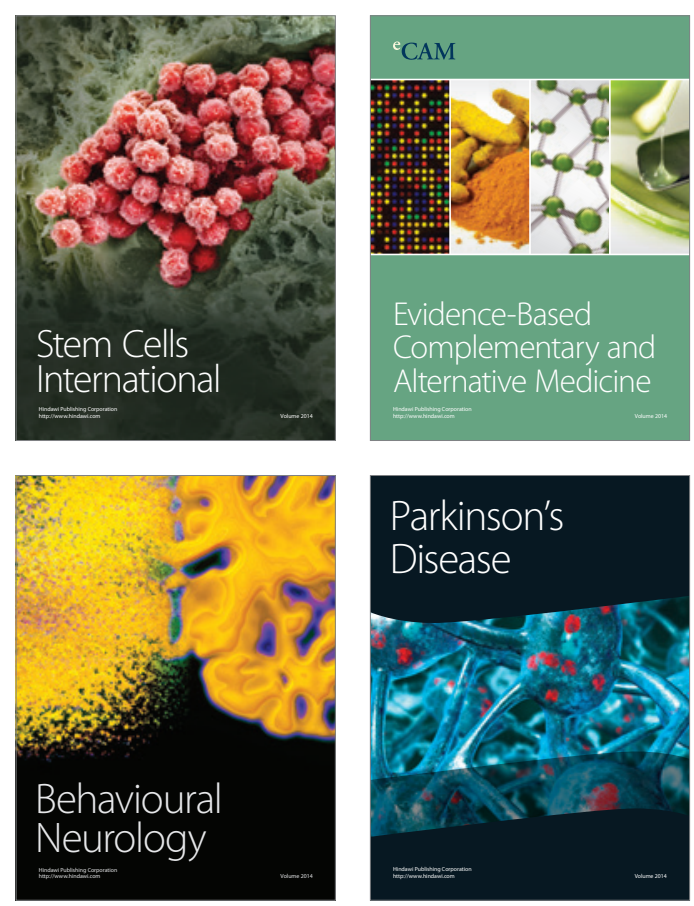

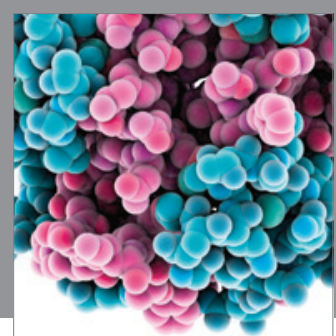

Journal of
Diabetes Research

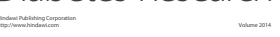

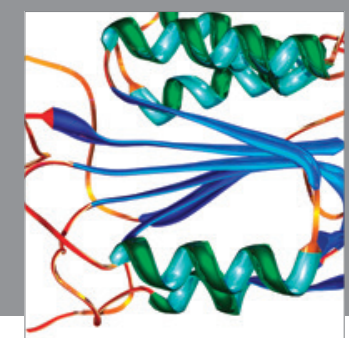

Disease Markers
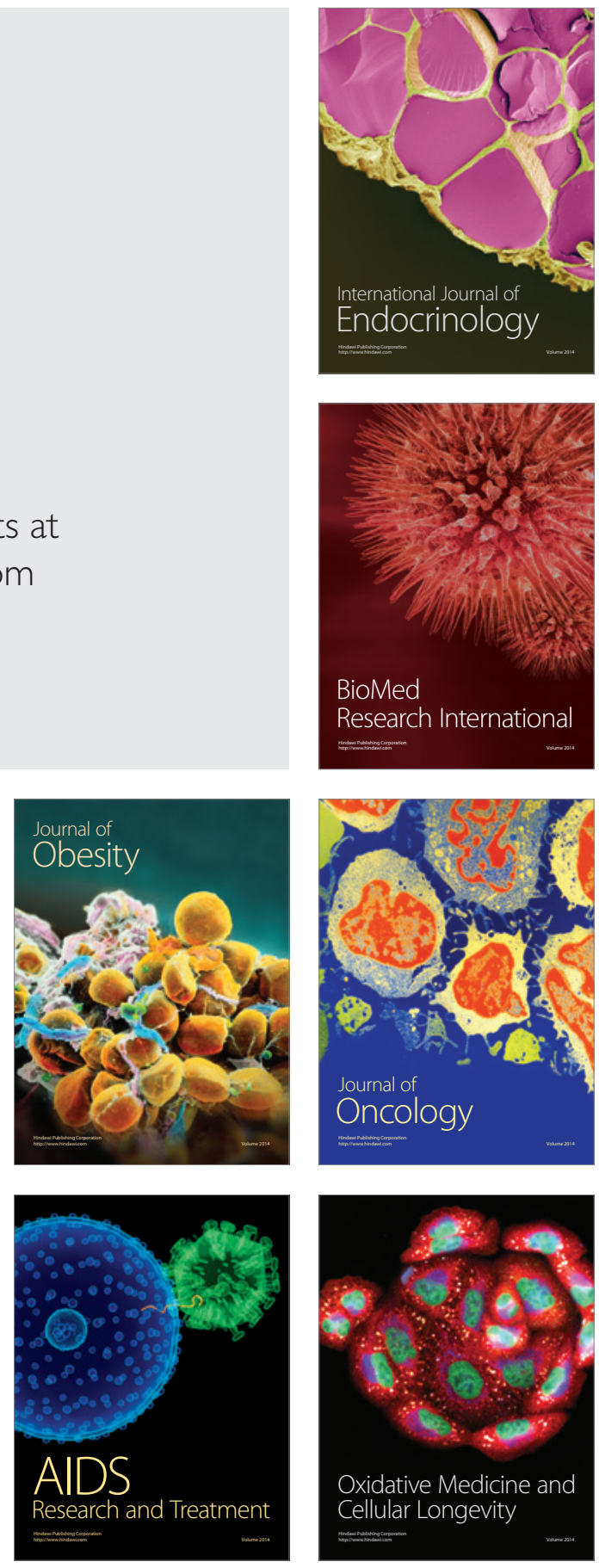